\title{
THE MOOD TYPES ANALYSIS IN SCRIPT OF RM'S SPEECH AT THE UNITED NATION
}

\author{
Resti Rahmawati $^{1}$, Dasep Suprijadi ${ }^{2}$ \\ 1,2 IKIP Siliwangi \\ ${ }^{1}$ resti.rahmawati@student.ikipsiliwangi.ac.id, ${ }^{2}$ dasep.suprijadi17@gmail.com
}

\begin{abstract}
This research discussed mood type analysis in script conveyed by Kim Nam Joon, better known under his performing name RM, leader of BTS (Bangtan Boys) at the United Nation about UN's Youth 2030 strategy. BTS get chosen as a UNICEF ambassador to front the "Love Myself" campaign in November 2018, which was part of UNICEF's \#ENDviolencecampaign. The objectives of this research are to identify the mood type and describe the interpretation of mood types. The researcher collected the data from The UNICEF website to get the script of the speech and this research used a qualitative descriptive method, which means the researcher analyzed the script. The speech consist of 719 words and 73 clauses, from the data, the researcher found three kinds of the mood types in this script, there are 63declarative, 3 interrogative, and 7Imperative. The result, the researcher concluded that RM's speech used declarative.
\end{abstract}

Keywords: BTS, Systemic Functional Linguistic, Interpersonal, Mood analysis

\section{INTRODUCTION}

Bangtan Boys known as BTS is one of the idol groups from Korea, debut in 2013, and has 7 members. BTS is Korean artists who go to international with their musical work and all the achievements that have been achieved internationally. In addition, BTS becomes a Korean group idol number one in the world. There is some BTS's achievement in the world, first in 2017 BTS performed at the American Music Award and bring them as the first Korean idol to perform in AMA, the other achievement in the same years they are getting some award in Billboard Music Award as a Top Social Artist, and the other achievement is BTS collaborating with various worlds artist, one of them is Hasley. In this year BTS become one of the performers at the prestigious American Grammy Award, this makes BTS add more achievement in the international arena.

From of the achievements achieved by BTS, made UNICEF interested choose BTS as an ambassador, they were chosen as an ambassador because they were influential among young people, therefore BTS was appointed by UNICEF to give a speech at the 73rd UN general assembly which was held at, New York, United States. The six-minute-long speech was delivered by the leader of BTS is Kim Nam Joon better know under his performing name RM, not only as a leader but also fluent in English, he was appointed to deliver the speech.

Tells about language has a function in communication, according to Halliday language is a way for making meaning and he adds there are three metafunctions, that are experiential, interpersonal, and textual metafunction. Metafunction is a part of Systemic Functional Linguistics. According to Noor (2016), the effective to analyze the language use semiotic term ways, which is Systemic Functional Linguistics. SFL is a linguistics approach, it was developed by M.A.K Michael Halliday, he is an Australian Linguist and He has been introduced by using 
discourse analysis. Systemic Functional Linguistics (SFL) is the learning of language which concerns with language as a resource of meaning. Systemic Functional Linguistic has a different name that is Systemic Functional Grammar is one of the theories of linguistics in a critical discourse approach (Uswatun Hasanah, 2019).

The SFL semantic component model is construed in terms of three metafunctions. There are; Ideational metafunction is a component of the meaning which focuses on the external way. Second, Textual metafunction is that part of the meaning potential which makes a text into a text. And the last, the interpersonal metafunction focused on the relationships between the speaker and his addressee(s), and between the speaker and his message (Sharififar \& Rahimi, 2015). It used to establish the speaker's role in the speech situation and relationship with the others (Almurashi, 2016)Interpersonal meaning has two components to analyze, are mood element and the residue element of the clause. The mood element consists of the subject, finite, and/or mood adjunct(Faidah, 2018).

According to Liping (2017), Mood puts how-to information is given either in spoken or written form. It is a part of the component to analyze interpersonal metafunction. The Mood System is the system of clauses as interpersonal resources. The mood system views a clause as an exchange. The mood system is built from the relation of mood structure between Subject and Finite. There are kinds of mood structures; The First, Declarative is the subject position of the speaker or writer is that of a giver (of information) and the addressee is position is that of the receiver. Declarative mood isthe most common way of providing information( $\mathrm{Yu}, 2017)$. Second, Imperative is the subject/writer position of asking something of the addressee or requesting them to do something, while addressee is supposed to comply. The clause is included in the imperative moodwhen there is no subject and the clause is starting with finite or predicator directly (Faidah,2018). Third, Interrogative is the speaker/writer asking information about the addressee, while the addressee is to provide information. The Interrogative is the type of indicative because the mood structure consists of Finite and Subject (Kusnadi,2018)

Due to the success of BTS in the world, and being able to give speeches in English so well, and able to attract the attention of people in the world, the researcher is interested in the influence of BTS's speech on the United Nation, although researcher analyzes the script of the speech delivered by The Leader of BTS. In this research, the researcher focused on the analysis mood type. Mood type is a part of interpersonal metafunction that consist of a subject and finite in some clause. From explained above, this research takes script the speech and analyze what is the mood types used in the speeches of RM's BTS and the interpretation of the mood types used in the script.

\section{METHOD}

In this research, the researcher used qualitative descriptive as a method. The researcher focused to analyze the script from the speech. Descriptive qualitative research method in purpose to identify the Mood analysis and the interpretation of mood type's use found in the script. The data were collected from a public speech by Kim Nam Joon, the leader of BTS. The process of collecting data is done through the following steps: first, the researcher searched the video of the speech and its script on The UNICEF website, second Read the script, Analyzed the data, after that the last step, wrote the report of the research into the table. 


\section{RESULTS AND DISCUSSION}

\section{Results}

This result presents the analysis of mood structure in the script from RM's speech. The data of this research taken from RM's Speech on September 28, 2018. It is discussed in the table of mood structure in Table 1 below :

Table 1 the result of mood structure

\begin{tabular}{lllll}
\hline MOOD & & & \\
& & & \\
ECLARATIVE & $\begin{array}{l}\text { IPERATIVE } \\
\text { LAUSE }\end{array}$ & $\begin{array}{l}\text { NTERROGRATIVE } \\
\text { LAUSE }\end{array}$ & OTAL \\
\hline CLAUSE NUMBER & $\mathbf{6 3}$ & & & \\
\hline PERCENTAGE & $\mathbf{8 6 , 3 \%}$ & $\mathbf{7}$ & $\mathbf{3}$ & $\mathbf{7 3}$ \\
\hline
\end{tabular}

\section{Discussion}

Based on table 1, this script produces seventy-three clauses that used three kinds of mood types, eighty-six point three percent declarative clause which is marked in form of statement clause, nine-point six percent imperative which is marked form of command clause, and four point one percent interrogative clause which is marked in form of question clause. From that data, the researcher discussed with some examples and brief explanations of each analysis. Data analysis in tabulated form is presented below:

1. Declarative Clause

Declarative clauses can be identified as clauses in which are included in the structural element position of the subject is before finite. The clause declarative mood is when the speaker(s) or writer (s) expressed by the statement. Declarative mood used in the speech are 63 clauses from the total 73 clauses, it is many clauses belong to declarative mood. These are the several examples of the declarative clause :

Table 2 declarative clause 1

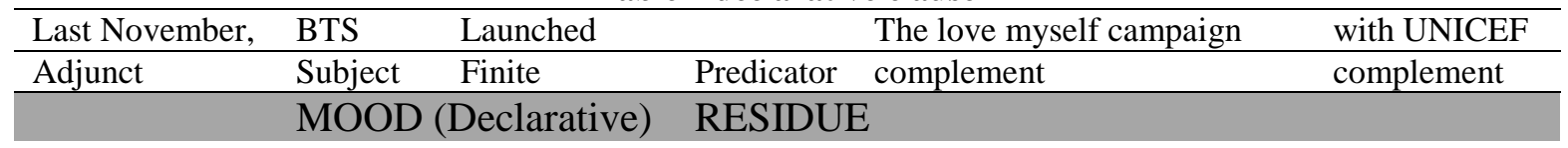

Table 3 declarative clause 2

\begin{tabular}{lllll}
\hline We & have & Been & partnering & With UNICEF \\
\hline Subject & Finite & Predicator & & Complement \\
\hline MOOD (Declarative) & RESIDUE & &
\end{tabular}

Table 4 declarativeclause 3 


\begin{tabular}{llllll}
\hline I & was & born & in Ilsan, & A city near Seoul, & South korea \\
\hline Subject & Finite & Predicator & Complement & & \\
\hline MOOD (Declarative) & RESIDUE & & &
\end{tabular}

Table 5 declarativeclause 4

\begin{tabular}{llllll}
\hline Soon, & I & began & To shut out & My own & voice \\
\hline Adjunct & Subject & Finite & Predicator & Complement & \\
& MOOD (Declarative) & RESIDUE &
\end{tabular}

Table 6 declarativeclause 5

\begin{tabular}{llllll}
\hline How, & Our massage & Helped & them overcome & their hardship & in life \\
\hline Adjuct & Subject & Finite/ Predicator & Complement & & \\
\hline \multicolumn{5}{c}{ MOOD (Declarative) } & RESIDUE
\end{tabular}

Table 2 into table 6, those are the example of the declarative clause, that mood structure analyzed. In this script, RM as a speaker gave more declarative clause, at the beginning of the speech, he gave information about the cooperation of BTS with UNICEF the clause are "Last November, BTS launched the love myself campaign with UNICEF" and "we have been partnering with UNICEF" this clause showed the declarative clause because the structure of the clause the position of the subject is before the finite. The structure of the mood we can see in tables 2 and 3. Before RM talked about his life, he gave information about his self, that clause is "I would like to begin by talking about myself" that clause showed the declarative clause. In table 3 that clause is "I was born in Ilsan, A city near Seoul, South Korea" RM began to talk about his life journey in childhood, he told where he is life, he told about the journey of BTS, and he told about how he caught the dream with all the mistake and try to listen to his self, From that the story he stated in clause 5 "How our message helped them overcome their hardship in life..." all the statement that gave RM made the young people in the world can help them in the hardship. According to Utomo et al., (2018), the Form of the statement which tells fact or information in some clause is the declarative clause.

\section{Imperative}

The second mood structure is discussed, which is an imperative clause. It can be identified as a clause that is included in a structural element when in the clause without a subject. The clause imperative mood is when the speaker(s) or writer (s) expressed by command. Imperative mood used in the speech are 7 clauses from the total 73 clauses, those are the several examples of the imperative clause :

Table 7 imperative clause 1

\begin{tabular}{llll}
\hline Started & to listen & to the voice & of others \\
\hline Finite & Predicator & Complement & \\
\hline MOOD & (Imperative) & RESIDUE &
\end{tabular}

Table 8 imperative clause 2

\begin{tabular}{|c|c|c|}
\hline Start & Loving & Themselves \\
\hline Finite & Predicator & complement \\
\hline MOOD (Imperative) & & \\
\hline
\end{tabular}


Table 9 imperative clause 3

\begin{tabular}{|c|c|c|c|c|}
\hline So, & lets & take all & one more & step \\
\hline Conj.Adjunct & Predicator & \multicolumn{3}{|c|}{ Complement } \\
\hline & MOOD & \multicolumn{3}{|c|}{ RESIDUE } \\
\hline
\end{tabular}

Table 10 imperative clause 4

\begin{tabular}{lll}
\hline Just, & speak & yourself \\
\hline & Finite & Complement \\
\hline & MOOD & RESIDUE
\end{tabular}

When the clause that the speaker wants to addressee does something, it is Imperative clause. The imperative clause is the form of the clause is command. In this script, the leader of BTS makes statements to those us as an addressee to do something. That found in the middle of the script when RM gave more motivation to young people in the world, one of those statements is "...., start loving themselves." The clause is sub-clause of the previous clause which is a declarative clause; this clause includes an imperative clause because the speaker wants the addressee to start loving themselves. The other clause that states the imperative clause is in table 9 and table 10, the clause is "so, let's take all one more step..." and "just, speak yourself", those sentences, Kim Nam Joon invite us to get one step to come forward and try to speak to ourselves, to get to know ourselves better than before, and try to love ourselves.

\section{Interrogative}

Interrogative clauses can be identified as clauses in which are included in structural elements adding WH-question or Polar. The clause interrogative mood is when the speaker(s) or writer (s) expressed by asking something or giving a question. Imperative mood used in the speech are 3 clauses from the total 73 clauses, those are the several examples of the interrogative clause:

Table 11 interrogative clause 1

\begin{tabular}{llll}
\hline what & is & your & name? \\
\hline Wh/C & finite & Subject & Complement \\
\hline RESIDUE & MOOD & (Interrogative) & \\
\hline
\end{tabular}

Table 12 interrogative clause 2

\begin{tabular}{lllllll}
\hline What & Excites & You & And & make & Your & heart Beat ? \\
\hline Wh/C & Finites & Subject & Conjct. & Finite & Subject & Complement \\
\hline RESIDUE & MOOD & & & MOOOD (Interrogative) & RESIDUE
\end{tabular}

This speech conveyed by Kim Nam Joon, Interrogative clause is less than the two types of clause, that have analyzed, in the clause the leader invited addressee to ask ourselves to understand ourselves, that clause is "What is your name?" with that clause, RM give the 
addressee to know about their selves. In this clause use form WH-question, in interrogative that is two forms; there are $\mathrm{WH}$-question and polar questions. The three interrogative clauses in this speech use the WH-question form.

\section{CONCLUSION}

This research took the script from the speeches of Kim Nam Joon as a sample to analyzed the mood types. All types of process which presented mood structure of RM's speech. The researcher found 73 clauses and three mood types in this script; there are Declarative, Imperative, and Interrogative. RM's speech produced $86.3 \%$ for Declarative, $9.6 \%$ for Imperative, and the last $4.1 \%$ for Interrogative. The dominant mood type used in the speeches is Declarative, indicates that the percentage of declarative is higher than imperative and interrogative and from the context in the speech, RM mostly talked information about himself, and tell about his life then and now, give information about BTS, followed by giving instruction and motivation, and the last he gave a question and command for the addressee at the end of the speech.

\section{ACKNOWLEDGMENTS}

Alhamdulillahirabbil'alamin, praise and thank you to Allah SWT. I would like to express my gratefulness who helped, guided, and supported in writing and finishing this article and praise God for the blessings given to authors so that I complete this article.

\section{REFERENCES}

Abdulrahman Almurashi, W. (2016). An Introduction to Halliday's Systemic Functional Linguistics. Journal for the Study of English Linguistics, 4(1), 70.

Faidah, C. L. (2018). Mood Analysis On Spoken Texts Of Teacher'sscaffolding Talks In English Subject. Thesis, Walisongo State Islamic, Education, semarang.

Hasanah, U., Alek, A., \& Hidayat, D. N. (2019). a Critical Discourse Analysis of Rm'S Speech. Jurnal Humaniora Teknologi, 5(2), 16-26.

Kusnadi, R. E. (2018). An Analysis Of Mood System In Utterances Between Poppy And Branch In Trolls Movie (Based On Systemic Functional Grammar). The State Islamic Institute Of Surakarta , English Education, Surakarta.

Liping, C. (2017). Mood, Modality and Polarity Analysis of Winston S. Churchill's Speech on Hitler's Invasion of the U.S.S.R. Advances in Social Sciences Research Journal, 4(1), 195-202.

Lufadeju, Y. (2018, September 24). UNICEF. Retrieved March 2, 2020, from https://www.unicef.org/press-releases/we-have-learned-love-ourselves-so-now-i-urgeyou-speak-yourself

Noor, M. (2016). Systemic Functional Linguistics Mood Analysis of the Last Address of the Holy Prophet (PBUH). International Journal of Language and Linguistics, 4(1),

Sharififar, M., \& Rahimi, E. (2015). Critical Discourse Analysis of Political Speeches: A Case Study of Obama's and Rouhani's Speeches at UN. Theory and Practice in Language Studies, 5(2), 343.

UNICEF. (2018, September 24). BTS speech at the United Nations | UNICEF. Retrieved March 2, 2020, from https://www.youtube.com/watch?reload=9\&v=oTe4f-bBEKg

Utomo, S., Rusiana, R., \& Minarosa, P. (2018). the Analysis of Mood Types in Steve Jobs' and 
Barack Obama'S Speeches. Refleksi Edukatika : Jurnal Ilmiah Kependidikan, 9(1).

$\mathrm{Yu}, \mathrm{H}$. (2017). Interpersonal Meaning of Mood and Modality in English Public Service Advertising Texts. 76(Emim), 222-227. 